\title{
'I am here and I am here to stay': the death and burial of soldiers with cholera during the Crimean War (1854-56)
}

\author{
Benoit Pouget Aix-Marseille Univ, CNRS, EFS, Ades, \\ Marseille, France \\ benoit.pouget@univ-amu.fr
}

\begin{abstract}
Based on a study of intersecting French archives (those of the Val de Grâce Hospital, the Service Historique de la Défense and the Archives Diplomatiques), and with the support of numerous printed sources, this article focuses on the handling of the bodies of French soldiers who died of cholera during the Crimean War (1854-56). As a continuation of studies done by historians Luc Capdevila and Danièle Voldman, the aim here is to consider how the diseased corpses of these soldiers reveal both the causes and circumstances of their deaths. Beyond the epidemiological context, these dead bodies shed light on the sanitary conditions and suffering resulting from years of military campaigns. To conclude, the article analyses the material traces left by these dead and the way that the Second Empire used them politically, giving the remains of leaders who died on the front lines of the cholera epidemic a triumphant return to the country and a state funeral.
\end{abstract}

Key words: cholera, epidemic, mass death, corpse, burial

\section{Introduction}

'The Crimean War represented one of the great medical disasters of all time.' ${ }^{1}$ Anticipating Richard A. Gabriel's harsh observation by a few decades, Friedrich Prinzing, whose work is based on publications by Gaspard Scrive and Jean-Charles Chenu two of the main French military doctors in the field - explained in 1916 the degree to which cholera alone had decimated the soldiers of the French expeditionary force: 'The total number of [cholera] deaths in the French army during the entire campaign was $12,467 .{ }^{2}$ For Jean-Claude Chesnais, epidemics had a major impact on soldier mortality in the Crimean War, since 'disease was apparently four times more deadly than the enemy's weapons. ${ }^{3}$ Profoundly affected by epidemics that overlapped in time and space (cholera, typhus), this military campaign clearly reveals 'the difficulties in inserting a large force into a distant operation' in the midst of degraded sanitary conditions. ${ }^{4}$ In a recent article Anne Rasmussen, basing her analysis on the writings of Alphonse Lavéran (the discoverer of protozoa and a pioneer in tropical medicine) and nineteenth-century French hygienists, points out how 
vulnerable French armies were to epidemics. ${ }^{5}$ Obviously, this risk increased during wartime, when wounds, fatigue and deprivation weakened bodies. It is not surprising, then, to find that among soldiers there was excess morbidity and excess mortality caused by exposure to epidemic diseases. ${ }^{6}$ What interests us here is first 'the fate of those killed in war, through what happens to their remains.7 The aim of this article is to examine the precise conditions in which French soldiers died and were buried in the midst of a mortality crisis that brought together the combined risks of war and epidemics (cholera) during the Crimean War (1854-56). This study looks at the situation prior to the 'break occurring in funeral practices in the West around the time of the First World War' that has been identified by Luc Capdevila and Danièle Voldman. ${ }^{8}$ The dead and their corpses are the focus of this article. Even though these soldiers fell fighting far from their homes and motherland, and died, in a sense, from combat, this combat took place outside of the traditional battlefield. It was against an unusual enemy, an invisible microbe unknown at the time: cholera. ${ }^{9}$ The cases of these soldiers, killed in war but not directly in combat, are part of a long line of military losses caused by exposure to an epidemic: war and epidemic disease are an age-old couple. ${ }^{10}$ Furthermore, 'until 1870, less than 20 per cent of military deaths occurred on the battlefield.'1 This was, for example, the case for the soldiers of the Great Army that died of typhus in Vilnius after their return from Napoleon's Russian campaign. ${ }^{12}$ Archaeological findings have thus 'revealed the demographic crisis context and the urgency [for proceeding] to quick burials. ${ }^{13}$ As for their friends who fell on the field of honour, their heroic deaths in the face of an invisible enemy following an intense struggle in an ambulance tent, within the walls of a military hospital or on the deck of a warship were all a part of the French military undertaking in the Crimean War. Their memory is kept alive today in the naming of Parisian streets, bridges and metro stations after these men and the battle victories of the was. The history of these French men who died of cholera must be thought of as being a key part of a long-term process that involves 'a particular way of dealing with the war dead and of creating a collective memory [that] has developed over a century and a half in Europe and on the continent of America.. ${ }^{14}$ The focus on the Crimean War is due especially to the size of the expeditionary force, deployed far from its bases in a heightened epidemic context, which itself led to a large-scale medical disaster, even though this war is traditionally presented as the first industrial conflict. ${ }^{15}$ My study is limited to the period of the conflict itself, from 1854 to 1856.

\section{The French dead on the front lines of cholera during the Crimean War}

\section{'My life leaks out at each breath': ${ }^{16}$ the appalling agony of cholera victims on the Eastern front}

In the nineteenth century, war continued to offer soldiers only suffering and death. Cholera attacked them quickly. When it did, 'death normally arrived in eight to ten hours; more extreme cases leading to a fatal result in three or four hours were not uncommon. ${ }^{17}$ The surgeon-major of the Mégère clearly established cholera's ability to appear without any warning signs and to include significant kinetics. During the 
second expedition on the Sea of Azov (spring 1855) while the Mégère was towing the Pomone long-boat and while 'all health conditions seemed [to be fine], all of a sudden three men from the Pomone were afflicted by a rapid onset of cholera.' ${ }^{18}$ Sailors Mélo, Méjean and Lepichon, 'all three full of vigour', succumbed in seven hours. On board the Iéna between 5 August and 23 September 1855 the epidemic followed a similar pattern. Of the forty-one cases, sixteen were fatal, and the nine patients who had a 'rapid onset of cholera' all died. ${ }^{19}$ On land, the results were just as deadly.

In addition to the speed with which cholera killed its victims, it was also a mass murderer. ${ }^{20}$ In August 1854, for example, the beaches of Varna became the theatre for a horror scene, directly attributable to cholera. On 8 August 1854 almost 3,200 sick men disembarked at Varna on their way to Constanţa and Mangalia in Romania. ${ }^{21}$ Scrive provides a vivid description of the degraded condition of the cholera victims. ${ }^{22}$ This horrific scene was also replayed on board French ships. Bernard Brousolle quotes the 'hallucinatory description', written by the surgeon on the Lavoisier, of the mass of cholera victims on the deck of his ship. ${ }^{23}$ In the end, from 3 to 31 July 1854, 2,123 cholera victims were cared for in Varna, and 1,413 of them died there; close to 70 per cent of the 7,156 soldiers participating in the Dobruja expedition died from the disease. ${ }^{24}$ According to Chenu again, while 'cholera dominated the situation' in the French hospitals in Constantinople in August 1854 (3,043 admitted out of 5,418 total), it led to 'unavoidable chaos' and was responsible for a large portion of the 3,015 deaths recorded in that month alone. ${ }^{25}$

\section{Medical observations of the blue death mask: post-mortem examinations and autopsies}

In the emanations of death left behind by cholera, the role of navy and army doctors did not just involve curative and palliative care, or simply counting the dead. In addition to supporting life until its final moments, these doctors participated more broadly in the medicalisation of death. Without any cynicism, it can be noted that the naval and military fronts of cholera provided an abundance of bodies for medicine: 'The medicalisation of death is part of a strategy of medical conquest, a field of expertise to be proud of. ${ }^{26}$ Faced with the corpses of cholera victims, the researcher-physician took over from the caregiver-physician: 'The research work done by doctors on campaigns also involved understanding the disease [...] autopsy work [then] became particularly important. ${ }^{27}$ In other words, 'the autopsy (or necroscopy or necropsy) made it possible to verify post-mortem whether or not a diagnosis was valid, and thus to advance knowledge. ${ }^{28}$ Before doctors proceeded to open up the flesh of cholera victims, they were puzzled by certain observations. Doctor Lebozec - a navy physician serving in Crimea - cannot explain why, for example, 'three-quarters of an hour or an hour after death, the periphery of the body seemed warm again' before this warmth dissipated 'very slowly. ${ }^{29}$ Similarly, he reports on the post-mortem observation of 'muscle movements that a few authors have mentioned (adducting and flexing movements of the forearms, fibrillar contractions of the face and the anterior part of the thorax) ${ }^{\prime 30}$ Autopsies were essential examinations for understanding how to treat cholera ante or post mortem, shaping the opinion 
of the doctor who performed them and strengthening his knowledge and medical considerations. They were common practice in military and naval contexts, ${ }^{31}$ and benefited from an effort to codify how to perform them: 'This standardisation policy [for autopsies at Rochefort] is based on logistics that seem very precise: cut, observe, diagnose, classify, catalogue. ${ }^{32}$ It is therefore not surprising to note that, during campaigns, military healthcare officers implemented the principles and techniques learned in military medical schools. ${ }^{33}$

Whether or not they were able to conduct a post-mortem examination, afterwards, doctors delivered the cholera-infected bodies of French soldiers to the military authorities and their comrades for burial.

\section{Handling of the corpses of cholera victims and burial methods}

\section{What was to be done with the corpses of cholera victims?}

The handling of remains on the front lines of the cholera epidemic involved a combination of regulatory, sanitary and logistical constraints. In military contexts, there is always 'a compromise between the attention given to the deceased and the material constraints that require quick action. ${ }^{34}$

Dying at sea led, for example, to consequences soberly summarised by Psalm 77:19: 'Thy way is in the sea, and thy path in the great waters, and thy footsteps are not known.' Jacques Léonard recalls the standard practice in effect on government ships: 'When someone died on board, the surgeon-major informed the commander and determined when to bury the body at sea; in the event of a pestilent fever, the effects of the deceased were also thrown overboard. ${ }^{35}$ Burial at sea was most often due to the fact that the body could not be kept without endangering the health of the crew and passengers. During periods of increased mortality risk due to the invasion of cholera, as was the case when Imperial Navy ships were repatriating French cholera patients from Dobruja to Varna in early August 1854, it is not surprising that the bodies were thrown into the sea as quickly as possible: 'The Calypso threw eighty corpses into the sea, the Primauget fifty, and the others as well in proportion to the number of their passengers, which was 340 for the Pluton, 300 for the Lavoisier, 450 for the Bertholet with the Fortuna in tow. ${ }^{36}$ Alain Cabantous has noted the degree to which burying the remains in the depths of the sea can represent 'a rift for the living still attached to the memory of their loved ones who are then deprived of a grave, that is, an identified place to contemplate and establish the memory of those who died. ${ }^{37}$ In the event that the death took place at sea, but not too far from a port of call or landing, the remains of cholera victims might avoid burial at sea. In one particular case the administrative procedure implemented corresponded to the framework of the order of 31 October 1827, which stated that 'as soon as a sick person died, the surgeon-major will provide an opinion to the second officer and the officer of the watch and to the administrative clerk, and inform them of when the deceased is to be buried. ${ }^{38}$ Accompanying the deceased until the end of their journey, doctors needed to be 'present at the burial of the dead. ${ }^{39}$ This was the reason why, at the end of June 1854, the Alexandre, on its way to the Eastern front, had to make a stop in Messina 'to unload its cholera victims. ${ }^{40}$ 
The soldier Alexandre Aberne, '24 years of age', died in the lazaretto, where he was buried. $^{41}$

\section{What places were used for burial? Were funerals held urgently in situations of mass death?}

When deaths from cholera peaked, the speed of burials increased. In the Mediterranean region, French cemeteries or plots in local cemeteries present a funerary geography of the Crimean War. This network of burial places can be superimposed onto the logistical line that extended from French Mediterranean ports to coasts on the Crimean peninsula. Not surprisingly, it was organised according to the main areas of intervention on the coast of the Black Sea and rear logistical hubs, which also played a role in funerals. They dotted the length of the 'pathological line', from the ports of Constantinople, the Bosporus and the Dardanelles to the ports of Corsica and the coasts of southern France (Marseilles, Toulon, Saint Mandrier, Porquerolles, Sainte Marguerite, Port Vendres ... ), along with the ports of Piraeus, Malta, Smyrna, Chania and Messina. ${ }^{42}$

During periods of mass deaths, the corpses of cholera victims were handled using emergency strategies. In close proximity to the front lines, the dead were buried in hastily built cemeteries on the edges of the camps. Sometimes, more summarily, 'at each bivouac, large graves were dug to bury the dead. ${ }^{33}$ It is worth remembering 'that collective burial does not necessarily imply negligence in caring for the bodies. ${ }^{44}$ César Lecat de Bazancourt - a historian of Napoleon III's campaigns also noted that in Gallipoli, 'graves were quietly dug around the camps. ${ }^{45}$ Bodies were buried in the earth and each received a measure of lime. Reverend Father Damas recalled that 'on the heights of Kamiesch, a lime kiln [burned] constantly [...] largely in order to provide a way of speeding the decay of the rotting corpses which no doubt, under the harsh sun, brought infection and death' ${ }^{46}$ Furthermore, in Varna the burials of 'patients who died' from cholera were taken care of by 'the French divisions themselves. ${ }^{47}$ Initially, these services were supposed to have been performed by 'grave diggers and workers from the country'. ${ }^{48}$ But when it became impossible to recruit grave diggers from among the local populations, frightened by the risks this entailed, the commanding officer of each division had to arrange 'urgently, in everyone's interest, duty' for burials. ${ }^{49}$

\section{What were the burial methods? What type of grave was used?}

Burial operations for corpses could, during mortality crises, be quite extensive. For example, on ' 31 July [1854] when the entire division arrived in Constanţa [. . .] 1,800 cholera victims awaited their turn to board the steam frigates; [it was at that time] that 1,200 corpses were placed in graves dug around this area. ${ }^{50}$ The technical process followed for these burials complied with a regulatory practice, as indicated by Chenu: not only were 'corpses to be covered by a metre of earth', but also 'a layer of quicklime was to be placed on [them].51 This practice of accelerating the decaying of the bodies went against the cultural revolution then taking place in civil cemeteries in France. Indeed, 'any solution that involved activating or accelerating the putrefaction of bodies became unthinkable in public opinion. ${ }^{52}$ But these 
were prophylactic measures taken to protect the living in an epidemic situation. The concern for hygiene, however, did not stop infected bodies, corpses that were potentially contagious, from being buried close to where soldiers lived. To understand this paradox, it should be remembered that 'until the 1870s, Pasteur's doctrine had not yet been recognised [even though already] connections were being made between water and epidemics. ${ }^{53}$ It was a balancing act in uncertain times. A more definitive explanation can be found by taking a more cultural approach.

The close proximity between burial sites and combat locations, barracks and where soldiers were billeted and cared for, which, beginning with the Crimean War, was documented, certainly foreshadowed the situation in the trenches from 1914-18. ${ }^{54}$ It reveals that in times of war the dead and the living coexist and share the same spaces, without a clear physical line of separation. In Crimea, the living soldiers did not avoid the dead, even if they had died of a contagious disease. One may venture to think that, in the end, the break that Capdevila and Voldman indicate occurred during the First World War, which was itself characterised by 'a rapprochement at the cultural level between those who were still alive and the bodies of those who had died' following 'the end of the nineteenth century [when] people's attitudes changed and they turned away from the presence of death in the world of the living, which they had been used to until then', can simply be explained by the separate dynamics at play in ordinary death and in death caused by war. ${ }^{55}$

For officers, burials were most often individual: 'A plot surrounded by walls served as a cemetery. Each officer had their own grave; soldiers lay together in large common graves. ${ }^{56}$ This distinction between how officers and soldiers were treated was part of a long-established practice: already under the First Empire, 'officers generally received special treatment. ${ }^{57}$ However, individual burials for noncommissioned soldiers were noted in Crimea, and at times they were for those who had died of cholera. The process was already underway that would lead to a rejection of collective military burials in the $1870 \mathrm{~s} .{ }^{58}$ Aside from this question, we can document (without dating it) a significant anthropological break with a practice which for centuries had meant that 'mortuary rituals had been discarded due to the urgency to deal with many potentially dangerous corpses. ${ }^{59}$ For example, the rifleman Gesta, like his friend Eymat, was buried in the Traktir camp on 23 December 1855 in the cemetery of the 1st division. Four of his comrades, along with the lieutenant commanding the company, assisted in the burial. ${ }^{60}$ There was a clear desire to provide a brother in arms with a dignified burial that combined 'the intentionality of the burial and a desire to conduct funeral rites. ${ }^{61}$ This practice of extending individual burials to non-commissioned soldiers thus counters the claim that 'combatants only rarely had individual graves' before the First World War. ${ }^{62}$ It would seem, with the evidence of the example of Crimea, that the individualisation of graves depended much more on quantitative uncertainties, that is, the volume of corpses to be buried, rather than on just the social status of the soldiers themselves.

\section{Cemeteries filled too quickly}

The massive and almost uninterrupted flow of cholera-infected corpses required, from the start of the conflict, that the spaces planned for burial be enlarged in 
the areas surrounding French hospitals and field hospitals, or close to billeting areas. In November 1854 the commander of the Belle Poule, in a letter sent to the vice-admiral commander-in-chief of the Black Sea squadron, was worried that the 'cemetery [of the navy in Beicos was] absolutely insufficient and would soon be filled'. ${ }^{63}$ This request, sent to the French chargé d'affaires, M. Benedetti, in Constantinople on 26 November, was, in addition to the issue of filling up the allocated space, based on an argument concerning 'the impracticality of these transports more than once a day (at the moment, in the hospital there are four bodies to be buried); [...] in addition to this consideration is the steeply sloped terrain of the current cemetery such that when it rains, the earth dug up by my shovels and carried away by the water leaves the caskets exposed, which also, aside from the distressing inconvenience, results in a high level of infection.' ${ }^{64}$ The chargé d'affaires then had to request a new concession from the Ottoman government, close to the navy hospital on the coast of Europe.$^{65}$ We can see, then, that the installation and extension of military cemeteries in the East required tense diplomatic negotiations between French representatives and their local counterparts. These negotiations did not end with the ending of the conflict and the departure of the expeditionary force. When French forces left the theatres of operation they left their dead behind, but did not abandon them. The 1856 Treaty of Paris, which ended the Crimean War, provided for the preservation of the cemeteries in Crimea. On 30 May 1856, when Yevpatoriya was returned to the Russians, 'Orders were given to enclose our cemeteries with dry stone walls and to raise or repair the graves. Cemeteries on the edges of the camp had to be transformed from what may have been closer to morgue stations, into long-term grave sites. ${ }^{66}$ Diplomats then took up the baton from their military counterparts. For example, a letter of 10 August 1856 documents the key role that the vice-consul of France in Gallipoli played 'for the prompt execution' of the construction of the French cemetery's outer walls. ${ }^{67}$ The walls were supposed to have been built with materials left behind by the French army, but they were insufficient. As a result, steps needed to be taken with the Ottoman authorities to gather 'some of the materials from walls [which belonged to them], currently in ruin, [which] would suffice for all of the military cemetery's outer walls. ${ }^{68}$ Negotiations dragged on even as the vice-consul continued his efforts, noting bitterly on 14 October 1856 that while the work on the British cemetery had been approved by the Ottoman governor, the French cemetery file was still suspended. ${ }^{69}$ On 28 December 1856 he had not given up on recovering the stones from the French military hospital walls and paved areas, in spite of the efforts of the Gallipoli customs officer to seize this resource for his personal business. ${ }^{70}$ In the same letter, the vice-consul also spoke of his difficulties in preserving the integrity of the 'markers raised up on the graves [which] were constantly destroyed by pillaging', since the Ottoman governor of Gallipoli could not 'post men' to watch over the cemetery. ${ }^{71}$ The French attention to ensuring that the remains of the soldiers who fell in Crimea were left undisturbed thus did not end with the Treaty of Paris and the departure of the French troops. Some of their flesh and bones were grouped together for several years after the end of the conflict, in common graves by unit, in the French cemetery in Sevastopol (built between 1870 and 1880). ${ }^{72}$ 


\section{Immediately remembering the dead fallen on the front lines of cholera: collections, monuments of memory}

Whether the bodies of cholera victims who died on the Eastern front were buried in the earth or disappeared into the deep, the living immediately took collective actions to remember the soldiers who had fallen victim to epidemics. These actions crystallised especially around collecting funds to build memorial spaces, assist cholera victims financially or contribute to supporting a charitable institution: 'Collections are always seen as collective and solemn gestures that pay homage to the deceased.73 In spring 1855 the French-English expeditionary force collected a fund in memory of the victims of cholera, and the soldiers and sailors from the two nations were asked to contribute. ${ }^{74}$ In May 1855 this resulted in the inauguration in Athens of a 'monument to the memory of the victims of the scourge: it is an obelisk in white marble bearing a dual inscription in French and English that recalls the number of leaders and the numbers of the regiments so cruelly decimated. ${ }^{75}$ The iron fence that encircles the monument is cared for by France's Ministry of the Navy. ${ }^{76}$ The inauguration was an opportunity to gather 'the entire French-English expeditionary force, officers of every rank and sailors from the division. ${ }^{77}$ The ceremony included a mass for the dead, a blessing and a parade of troops in front of the French Ambassador and the commanding officers positioned close to the monument situated on a fairly elevated headland overlooking the Phaleron plain. ${ }^{78}$ It celebrated the memory of those soldiers who had fallen victim to cholera and who were laid to rest in the East.

\section{The exceptional return of the bodies of cholera patients to France}

\section{The regulatory framework for the repatriation of the deceased}

When death occurs far from the home country, on foreign seas or lands, or in the colonies, there may be a question as to the appropriateness of repatriating the remains of the deceased. In the case of France, specific regulations applied. Instructions dated 20 September 1855, for example, regulated the conditions 'for the burial and transport to France of the remains of persons who died in Algeria and/or in foreign countries subject to military rule by French occupation. ${ }^{79}$ This procedure could be begun when families requested it (art. 1), and was ruled on by a 'military official' (art. 2) ${ }^{80}$ When a positive decision was given, doctors and military health officers were then responsible for conducting the exhumation (art. 3). ${ }^{81}$ The exhumed body would be placed in a lead casket within an exterior oak casket (art. 4). ${ }^{82}$ The human remains inside these two caskets were covered 'by a mixture composed in equal parts of dried sawdust and zinc sulphate to fill the coffin' (art. 5). ${ }^{83}$ Once sealed, the casket was then delivered to the family, who were responsible for arranging 'with the captain of a commercial ship that the casket be loaded and transported to France' (art. 6). ${ }^{84}$ This request was made to the relevant departments for the deceased (Ministry of the Navy and the Colonies, Ministry of War). Transport costs were the family's responsibility. ${ }^{85}$ Ten copies of this regulation were sent to the Ministry of the Navy by the Ministry of War on 29 October 1855, in order to ensure the widest possible distribution. ${ }^{86}$ 


\section{The return of the remains of heroic leaders of the Crimean War: Marshal Saint-Arnaud and Admiral Bruat}

A few exceptional cases were not subject to the regular burial rules in place. These involved high-level persons who had died of cholera in the East. True heralds of the Crimean War, their remains could not be left far away from France. The transport and return of their remains were an opportunity to celebrate their individual glory as well as that of the young political regime of Napoleon III. Thus, 'on 29 September [1854] at $10 \mathrm{AM}$, sailors from the Berthollet arrived to take the dying Marshal Saint-Arnaud to transport him to their ship and settle him in a wellventilated cabin. As the ship was sailing to Constantinople, the marshal died in the afternoon. ${ }^{\text {,7 }}$ The French chargé d'affaires in Constantinople announced the death to his successor, General Canrobert, on 1 October. ${ }^{88}$ The marshal's remains were then left in the 'embassy chapel', where his body was embalmed before returning to France by sea. ${ }^{89}$ The remains left Constantinople on 4 October 1854 for Marseilles, 'in accordance with the orders of General Canrobert.. ${ }^{90} \mathrm{~A}$ funeral procession across the Mediterranean then accompanied the marshal's dead body. As François Maspéro summarises it: 'In every port, the cannons thundered. ${ }^{91}$ Indeed, the passage of the Berthollet into the Sea of Marmara was saluted by nineteen cannon shots from the batteries of the Bosporus. ${ }^{92}$

Once the marshal's casket arrived in Paris on 16 November, in accordance with the orders of the emperor, it was placed in the vaults of the Hôtel des Invalides following a majestic ceremony. ${ }^{93}$ The state covered the cost of the state funeral, based on the provisions established by the Prince-President in 1852 to charge the 'costs for funerals of marshals' to the Ministry of War budget. These provisions had been put forward by his Minister of War at the time, the Marshal Saint-Arnaud himself. ${ }^{94}$ The ceremony, for its part, followed an exact programme which, in addition to the route taken by the procession (from the Rue de Lyon to the Esplanade des Invalides), regulated the music and military escort that accompanied the marshal to his final resting place. ${ }^{95}$ An eloquent account of the ceremony can be found in the memoirs of the soldier Pierre Bouhourt. ${ }^{96}$

Shortly thereafter, the splendour of the return of Saint-Arnaud's remains gave way to a harsher reality. Before the vault was permanently sealed, it was noticed that 'the body, instead of being embalmed and enclosed in a lead casket [in accordance with the regulation and custom], had been simply placed in a bath of wine spirits and then in a zinc coffin enclosed within a wood casket that was much too large. ${ }^{97}$ Aside from the risk of infection, which was certainly a part of the handling and moving of the remains of a cholera victim over close to $3,500 \mathrm{~km}$ first by boat, then by train and finally in a hearse, this case clearly reveals that it was difficult to find a lead casket on Ottoman soil in the short period of time between the death of the marshal and the departure of his remains to France. Very quickly, then, the Parisian funeral administration tried to rectify the situation, which presented a risk for its staff: 'A plumber was immediately sent to the vault for this purpose [who began by soldering a lead cap on the cork placed on the cover of the zinc casket. ${ }^{98}$ Only then was the zinc casket placed in a 'lead casket that was itself contained in another oak casket." ${ }^{99}$ The remains of Marshal Saint-Arnaud are thus resting in a triple sarcophagus. 
A similar post-mortem triumph followed the return of the remains of Admiral Bruat to France. Among the sailors who died from cholera during the Crimean campaign, Admiral Bruat was the highest-ranking victim: 'Struck by cholera, our admiral died after a few hours of horrible suffering. ${ }^{100}$ He died at sea on 19 November 1855 and 'the Montebello, in mourning, brought his remains back to Toulon. ${ }^{101}$ As indicated by Auguste Marroin, the chief navy medical officer in Crimea, while his death certainly prevented him 'from being lauded as a victor' during his life, his remains received the honours due to a 'commander [who had demonstrated] so many strong qualities. ${ }^{102}$ The funeral honours he received followed the instructions in the order of 31 October $1827 . .^{103}$ When news of his death reached Toulon, it was decided to 'hold a funeral and religious ceremony on land with the costs borne by the navy. ${ }^{104}$ Upon the decision of the maritime prefect of Toulon, orders were given for his remains to be returned on a vessel that 'would fly the flags of the admiral at half-mast, as well as the national colours' (art. 1). ${ }^{105}$ On 5 December 1855, the assumed date when the Montebello would arrive in the bay of Toulon, the plan was to have the body leave the vessel and be placed 'in the Admiral's boat' with the 'general staff and the chief chaplain' on board (art. 5). ${ }^{106}$ A procession of boats was to accompany the admiral's final naval voyage to the port of Toulon before his body was placed in a cenotaph 'put in the arsenal across from the clock tower' (art. 7). ${ }^{107}$ After a ceremony conducted according to articles 8 to 14, the body of Admiral Bruat was to be 'loaded and transported on board the Primauguet' (art. 14). ${ }^{108}$ These provisions were implemented 'on 5 December [when] the Montebello dropped anchor in the port of Toulon where it was bringing the remains of the former commanderin-chief of the French flotilla.. ${ }^{109}$ The voyage of the admiral's body ended like that of Marshal Saint-Arnaud, under the cupola of the Hôtel des Invalides in Paris: After the first funeral ceremonies in Toulon, the body was transported to Paris, where the government honoured it with the glorious and well-deserved funeral at Les Invalides.'110

The cholera-infected bodies of Saint-Arnaud and Bruat, killed in the whirlwind of epidemics, were received with the same consideration shown to the great French officers who had died with their weapons drawn., Their reception at Les Invalides was a mark of the country's recognition both of their service to the Second Empire and of the life they had sacrificed on the Eastern front. Being killed by cholera rather than by a shell did not in any way diminish their greatness. ${ }^{111}$

\section{Conclusion}

This study sought to document how funerals were handled during an epidemic in the midst of war. At the intersection of these two crises, the aim was to understand, in addition to the experience of dying and death, how, in the mid-nineteenth century, corpses with two overlapping characteristics - dying for one's country far from France and succumbing to an epidemic disease - were treated. In periods of mass death, these remains were first examined during a post-mortem consultation, sometimes by an autopsy. The causes of death were verified, which contributed to the knowledge of a disease whose microbial agent was as yet unknown to doctors. Once 
they were returned from medical science, the corpses were buried in accordance with a regulatory framework and practice that corresponded both with the customs of the time and the constraints imposed by military operations. In the kaleidoscope of circumstances surrounding the deaths of cholera victims, there were a range of funeral situations (burial at sea, collective graves, individual graves) that need to be viewed in relation to dynamics that played out over a longer term. The slaughter caused by cholera thus contributed to growing tensions related to burial sites. Efforts to establish and expand such sites in foreign lands required firm negotiations with local authorities. These dealings provided the outlines for genuine funeral diplomacy. The memory of those who had died from cholera - who were heroes of the epidemic furore, just like their comrades who fell under enemy fire - is inscribed at the very sites where these massacres took place, through monuments erected in their memory and the absence of discrimination based on the cause of death. Their inclusion in the national French military undertaking reached its height with the return of the cholera-infected remains of Marshal Saint-Arnaud and Admiral Bruat. The forms of farewell to these two leaders, in addition to being part of a historical continuity (these forms were followed, most notably, when the ashes of Napoleon I were returned), were also used to legitimise the policy of a new regime and foreshadowed the changes that were to come to public, individual and collective funerals for military servicemen who died in war. ${ }^{112}$ The funerary handling of the corpses of cholera victims in Crimea brings together, within the same time period (when it was materially possible), funeral rites and the establishment of a collective memory of epidemics. In so doing, it mitigated the past practice of excluding persons who had died from an epidemic. ${ }^{113}$ Better still, these diseased bodies received a triumphant welcome upon their return to France and made it impossible for death by an epidemic disease to efface military glory.

\section{Notes}

Translated from French and edited by Cadenza Academic Translations.

1 R. A. Gabriel, Between Flesh and Steel: A History of Military Medicine from the Middle Ages to the War in Afghanistan (Washington, DC, Potomac Books, 2013), p. 152.

2 F. Prinzing, Epidemics Resulting from Wars (Oxford, Clarendon Press and London, H. Milford, 1916), p. 172.

3 J.-C. Chesnais, Les morts violentes en France depuis 1826: Comparaisons internationales (Paris, INED-PUF 1976), p. 170. [Translator's note: Our translation. Unless otherwise stated, all translations of cited foreign language material in this article are our own.]

4 F. Cochet, Être soldat. De la révolution à nos jours (Paris, Armand Colin, 2013), p. 106.

5 A. Rasmussen, 'Expérimenter la santé des grands nombres: Les hygiénistes militaires et l'armée française, 1850-1914', Le Mouvement Social, 257:4 (2016), 71-91. 
6 G. Jorland, 'La variole et la guerre de 1870', Les Tribunes de la santé, 33:4 (2011), 25-30.

7 L. Capdevila and D. Voldman, War Dead: Western Societies and the Casualties of War, trans. Richard Veasy (Edinburgh: Edinburgh University Press, 2006), p. xiii.

8 Ibid., p. xii.

9 P. Bourdelais and J.-Y. Raulot, Histoire du choléra en France: une peur bleue: 1832-1854 (Paris, Payot, 1987).

10 F. Guilhaumon, La Guerre et les épidémies d’après les mémoires de la société médicale des sciences de Metz (Paris, Pichon-Lamy and Dewez, 1869).

11 Capdevila and Voldman, War Dead, p. 6.

12 D. Raoult, O. Dutour, R. Jankauskas, L. Houhamdi, P.-E. Fournier et al., 'Evidence for Louse-transmitted Diseases in Soldiers of Napoleon's Grand Army in Vilnius, Journal of Infectious Diseases, 193:1 (2006), 112-20.

13 T. Vette, A. Homann, K. Sczech, S. Bock, M. Signoli, 'De la campagne de Russie à la campagne d'Allemagne: quatre exemples d'apports de l'archéologie et de l'anthropologie funéraire à nos connaissances sur le Premier Empire', Cahiers d'etudes et de recherches du musée de l'Armée, 5 (2009), 61-82.

14 Capdevila and Voldman, War Dead, p. xv.

15 M. Lemaire, 'La guerre de Crimée: Chronique et analyse d'un désastre sanitaire (1854-1856)', PhD dissertation, Université Montpellier III, 2006; M. Battesti, La Marine de Napoléon III: Une politique navale, vols I and II (Chambéry-Vincennes, Laboratoire d'archéologie maritime et Service historique de la Marine, 1997), p. 156; B.-H. Reid, Atlas des guerres: L’âge industriel: Guerre de Crimée, guerre de Sécession, unité allemande: 1854-1871 (Paris, Autrement, 2001).

16 A. De Lamartine, Le Poète mourant, 1858.

17 Annual medical reports or reports given at the end of campaigns by the doctors and surgeons of the French Navy, Service Historique de la défense (Defence Historical Service) Vincennes (SHD/V), series CC $^{2}$, box 958.

18 Annual medical reports or reports given at the end of campaigns by the doctors and surgeons of the French Navy, Service Historique de la défense Toulon branch (SHD/T), box X, report no. 37 .

19 Annual medical reports or reports given at the end of campaigns by the doctors and surgeons of the French Navy, SHD/T/III/25.

20 Order of 31 October 1827, Annales maritimes et coloniales officielles, vol. 31-1827, pp. 96, 143, 149.

21 Letter from the general staff of the Eastern Army in Varna to the commanding general of the cavalry division, 8 August 1854, SHD/V/G/5.

22 G. Scrive, Relation médico-chirurgicale de la campagne d'Orient: du 31 Mars 1854, occupation de Gallipoli, au 6 Juillet 1856 évacuation de la Crimée (Paris, Victor Masson, 1857), pp. 10-11.

23 B. Broussolle, 'Le service de santé de la Marine pendant la guerre de Crimée, Toulon, le Var et la Mer sous le Second Empire, Proceedings of the round table of Friday, 13 December 1996, pp. 57-66; Annual medical reports or reports given at the end of campaigns by the doctors and surgeons of the French Navy,

SHD/T/III/19: 'It is impossible to imagine the hideous spectacle we saw before our 


\section{Benoît Pouget}

eyes, three hundred men who were rolling around on deck, twisting their limbs in spasms of pain, tormented by intense thirst that nothing could quench, they emitted terrible cries... Every now and then, I provided combat and cleaning buckets to receive the evacuations of those who had enough strength to drag themselves over to them. Much of it filled their clothing and the sails that served as their beds. Their evacuations soaked into the deck to such a point that eight days after it had all been removed, the foul smell arose again whenever the decks were scrubbed. This scene went on for thirty hours, and twenty among them died or were thrown overboard a few hours after their death.' This account of the horrible suffering caused by the cholera that affected French soldiers and sailors is corroborated by a letter sent by the commander of the Lavoisier to the maritime prefect of Toulon, August 1854, SHD/T/2A6/272.

24 J.-C. Chenu, Rapport au Conseil de santé des Armées sur les résultats du service médico-chirurgical aux ambulances de Crimée et aux hôpitaux militaires français en Turquie, pendant la campagnes d'Orient en 1854-1855-1856 (Paris, Masson, 1865), p. 28.

25 Ibid., p. 40.

26 A. Carol, 'Prêtres et médecins face à la mort et aux mourants en France, XIXe-1e moitié du XXe siècle', Rives nord-méditerranéennes, 22 (2005), 109-24.

27 C. Fredj, 'Médecins en campagne, médecine lointaine. Le service de santé des Armées dans les expéditions lointaines du Second Empire (Crimée, Cochinchine, Mexique)', thesis supervised by Daniel Nordman (EHESS), 2006, p. 771.

28 A. Carol, Les médecins et la mort, XIXe-XXe siècle (Paris, Éditions Aubier, 2004), p. 256.

29 J.-A.-M. Lebozec, 'Relation médicale de la campagne du vaisseau l'Alger dans la mer Noire, principalement pendant son séjour dans la baie de Kamiesh', thesis, Montpellier, 1858, p. 53.

30 Ibid.

31 G. Beriet, 'Lautopsie à l'école de médecine navale de Rochefort. L'heuristique du mort en question (1810-1850)', Frontières, 23:1 (2010), 60-5; E. Belmas, 'Respecter les défunts en servant la science: la dépouille des soldats décédés dans les hôpitaux militaires français (XVIIe-XVIIIe siècles)', in E. Belmas and S. Nonnis-Vigilante (eds), Lorchestration de la mort. Les funérailles, des temps modernes à lépoque contemporaine (Lille, Presses du Septentrion, 2017), pp. 53-64; C. Thambirajah, 'Autopsier dans la Marine française en Méditerranée au XIXe siècle: documenter l'“ouverture" des corps en contexte militaire naval à partir des archives', Master's 2 thesis, Aix-Marseille University, 2018.

32 Beriet, 'Lautopsie à l'école de médecine navale de Rochefort.'

33 Ibid.: 'While there was unanimous theoretical interest in corpses as objects of physiological knowledge, actually carrying this out experienced a number of obstructions [...]. Aside from disgust at the decay of precious dissection material, autopsies of cadavers seemed to be a rite in the anthropological sense, a way of proving oneself and thus demonstrating one's abilities to care for bodies.'

34 J. Hantraye, 'Les sépultures de guerre en France à la fin du Premier Empire', Revue d'histoire du XIXe siècle, 30:1 (2005), 8. 
35 J. Léonard, Les Officiers de Santé de la Marine française de 1814 à 1835 (Paris, C. Klincksieck, 1967), p. 97.

36 Letter from the Superior Commander of the Navy at Varna to the Minister of the Navy, 9 September 1854, SHD/V/BB $4 / 719$.

37 A. Cabantous, 'Le corps introuvable. Mort et culture maritime (XVIe-XIXe siècles)', Histoire, économie et société, 9:3 (1990), 321-36: 'Suddenly engulfed or thrown into the sea after a brief ceremony, the immersed body is a body that disappears, obliterating any tangible trace for the living, and excluding any topography of memory.'

38 Order of 31 October 1827, Annales maritimes et coloniales officielles, vol. 31-1827, pp. 96, 143, 149.

39 Ibid.

40 Letter from the vice-consul of France in Messina to the Foreign Affairs Minister, 30 June 1854, Centre des archives diplomatique de la Courneuve (CADC) (Diplomatic Archives Centre of La Courneuve), series CCC, MESSINA post, box no. 1793.

41 Ibid.

42 Chenu, Rapport au Conseil de santé des Armées, p. 21.

43 L. Baudens, La guerre de Crimée. Les campements, les abris, les ambulances, les hôpitaux, etc. (Paris, Michel Lévy Frères, 1858), p. 187.

44 Hantraye, 'Les sépultures de guerre en France à la fin du Premier Empire'.

45 C. L. de Bazancourt, Lexpédition de Crimée jusquả la prise de Sébastopol: chroniques de la guerre (Paris, Amyot, 1857), p. 98.

46 A. Damas, Souvenirs religieux et militaires de la Crimée (Paris, J. Lecoffre, 1857), p. 11.

47 Letter from the chief of staff of the general staff to the commanding officer of the 4th infantry division, 14 August 1854, SHD/V/GR/G1/5.

48 Ibid.

49 Ibid.

50 Baudens, La guerre de Crimée, p. 184.

51 Chenu, Rapport au Conseil de santé des Armées, p. 86.

52 A. Carol, 'Perception et gestion hygiéniste des cimetières en France au XIXème siècle', in A. Carol and R. Bertrand (eds), Aux origines des cimetières contemporains (Aix-en-Provence, Presses universitaires de Provence, 2016), pp. 159-76.

53 Ibid.

54 Capdevila and Voldman, War Dead, p. 17.

55 Ibid.

56 Baudens, La guerre de Crimée, p. 93: 'A plot surrounded by walls served as a cemetery. Each officer had their own grave; soldiers lay together in large common graves.' See Capdevila and Voldman, War Dead, p. 25: 'Ordinary troops who died [...] were placed in trenches rather than individual graves.'

57 Hantraye, 'Les sépultures de guerre en France à la fin du Premier Empire.

58 D. Tartakowsky, Nous irons chanter sur vos tombes. Le Père-Lachaise, XIXe-XXe siècle (Paris, Éditions Aubier, 1999), pp. 50 and 52.

59 G. Clavandier, La mort collective: Pour une sociologie des catastrophes (Paris, CNRS éditions, 2014), p. 191. 


\section{Benoît Pouget}

60 Eymat death report, SHD/V/G/259.

61 J. Leclerc, 'La notion de sépulture', Bulletins et mémoires de la société d'anthropologie de Paris, 2:3 (1990), 13-18.

62 Capdevila and Voldman, War Dead, p. 8.

63 Letter from the commander of the Belle Poule to the commander of the Black Sea squadron, 4 November 1854, SHD/V/BB4/696.

64 Letter from the commander of the Belle Poule to the chargé d'affaires for France in Constantinople, 26 November 1854, Centre des archives diplomatiques de Nantes (CADN) (Diplomatic Archives Centre of Nantes, Constantinople post, series 166 PO E box 729 .

65 Ibid.

66 On the distinction between mortuary spaces and funeral spaces in contexts of mass violence, see É. Anstett, 'Qu'est-ce qu'un charnier? Traitement des dépouilles et dépôts multiples dans les contextes contemporains de violences de Masse', in Michel Lauwers and Aurélie Zemour (eds), Qu'est-ce qu'une sépulture? Humanité et systèmes funéraires de la Préhistoire à nos jours (Actes des XXXVIe rencontres internationales d'archéologie et d'histoire d'Antibes), (Antibes, Editions APDCA, 2016), pp. 279-92.

6710 August 1856, CADN/GALLIPOLI/166PO/D29.

68 Letter from the vice-consul of France in Gallipoli to the French ambassador in Constantinople, 10 September 1856, CADN/GALLIPOLI/166PO/D29.

6914 October 1856, CADN/GALLIPOLI/166PO/D29.

7028 December 1856, CADN/GALLIPOLI/166PO/D29.

71 Ibid.

72 C. Lahure, Histoire populaire contemporaine de la France, vol. 3 (Paris, Hachette, 1865), pp. 283-5.

73 E. Fureix, 'Souscrire pour les morts. Un don politique sous la Restauration et la Monarchie de Juillet', Hypothèses, 1 (2001), 275-85.

74 Letter from the commander-in-chief of the naval division of the Levant and expeditionary force in Greece, 23 May 1855, SHD/V/BB4/722.

75 Ibid.

76 Ibid.

77 Ibid.

78 Ibid.

79 Instructions dated 20 September 1855 regulating the conditions 'for the exhumation to France of persons who died in Algeria and/or in foreign countries subject to military rule by French occupation, $\mathrm{SHD} / \mathrm{V} / \mathrm{BB}^{3} / 689$.

80 Ibid.

81 Ibid.

82 Ibid.

83 Ibid.

84 Ibid.

85 Ibid.

86 Letter from the Minister of War to the Minister of the Navy, 29 October 1855, $\mathrm{SHD} / \mathrm{V} / \mathrm{BB}^{3} / 689$. 
87 M. Lemaire, 'La guerre de Crimée', p. 170.

88 Letter from the French ambassador in Constantinople to the commander-in-chief of the Eastern Army, 1 October 1854, CADN/CONSTANTINOPLE/166POE/735.

89 Ibid.

90 Letter from the captain of the Berthollet to the commander-in-chief of the Black Sea squadron, 2 October 1854, SHD/V/BB4/696.

91 François Maspéro, L'Honneur de Saint-Arnaud (Paris, Seuil, 1993).

92 Letter from the chargé d'affaires for France in Constantinople to the Foreign Affairs Minister, 4 October 1854, SHD/V/GR/7N/1631.

93 Letter from the Minister of War to the governor of Les Invalides, 12 October 1854, SHD/V/GR1/XY/11.

94 Report to the Prince-President of the Republic on 7 May 1852 by the Minister of War SHD/V/GR/1/M/2222.

95 Ceremonial programme adopted for the funeral of Marshal Saint-Arnaud with the letterhead of the Minister of War, SHD/V/GR1/XY/11.

96 Letter from Pierre Bouhourt, pensioner of the Hôtel des Invalides, to his daughter, 18 October 1854.

97 Letter from the quartermaster of Les Invalides to the governor of Les Invalides, 16 October 1854, SHD/V/GR/1/XY/11.

98 Ibid.

99 Ibid.

100 A. Marroin, Histoire médicale de la flotte française dans la mer Noire pendant la guerre de Crimée (Paris, J-B. Baillière, 1861), p. 188.

101 E. Gourdon, Histoire du Congrès de Paris (Paris, Librairie Nouvelle, 1857), p. 321.

102 Marroin, Histoire médicale, p. 195.

103 Order of 31 October 1827, art. 709, Annales maritimes et coloniales officielles, vol. 31-1827, pp. 96, 143, 149.

104 Order of the maritime prefect of Toulon, 3 December 1855, SHD/T/2A7/146.

105 Ibid.

106 Ibid.

107 Ibid.

108 Ibid.

109 L. Guerin, Histoire de la dernière guerre de Russie (1853-1856) (Paris, Dufour, Mulat and Boulanger, 1858), p. 515.

110 Ibid.

111 R. d'Aiguy, Une vie (Paris, Librairie Nouvelle, 1862), p. 151: 'In this way, the war ended, one of the most striking of this century. Its last great victim was Admiral Bruat, whose flag caused the shores of the Sea of Azov to tremble. A fact is that none of them fell in the heat of battle [...]. Bruat died, like Saint-Arnaud, while returning to France, where the honours of triumph awaited him, and his illustrious remains went to lie alongside those of his brother in arms, in the glorious sanctuary founded by the greatest of monarchs.'

112 This is the general purpose of Capdevila and Voldman, War Dead.

113 M. Colardelle, 'La mémoire des exclus - Réflexions archéologiques et historiques sur la maladie et la mort épidémique’, Ethnologie Française, 28:1 (1998), 21. 